Abstracta Iranica Abstracta Iranica

Revue bibliographique pour le domaine irano-aryen

Volume 40-41 | 2019

Comptes rendus des publications de 2017-2018

\title{
Anthony Comfort \& Michał Marciak. How Did the Persian King of Kings Get his Wine? The upper Tigris in antiquity (c.700 BCE to $636 \mathrm{CE}$ )
}

\section{Astrid Nunn}

\author{
(2) OpenEdition \\ Journals \\ Édition électronique \\ URL : http://journals.openedition.org/abstractairanica/48690 \\ DOI : 10.4000/abstractairanica.48690 \\ ISBN : 1961-960X \\ ISSN : 1961-960X \\ Éditeur : \\ CNRS (UMR 7528 Mondes iraniens et indiens), Éditions de l'IFRI
}

\section{Référence électronique}

Astrid Nunn, « Anthony Comfort \& Michał Marciak. How Did the Persian King of Kings Get his Wine? The upper Tigris in antiquity (C.700 BCE to 636 CE) », Abstracta Iranica [En ligne], Volume 40-41 | 2019, document 10, mis en ligne le 30 octobre 2019, consulté le 17 avril 2021. URL : http://

journals.openedition.org/abstractairanica/48690; DOI : https://doi.org/10.4000/abstractairanica. 48690

Ce document a été généré automatiquement le 17 avril 2021.

Tous droits réservés 


\title{
Anthony Comfort \& Michał Marciak. How Did the Persian King of Kings Get his Wine? The upper Tigris in antiquity (c.700 BCE to 636 CE)
}

\author{
Astrid Nunn
}

\section{RÉFÉRENCE}

Anthony Comfort \& Michał Marciak. How Did the Persian King of Kings Get his Wine? The upper Tigris in antiquity (c.700 BCE to 636 CE). Oxford: Archaeopress, 2018, 146 p.

1 La région au centre de cette petite monographie, celle du Haut Tigre, a connu un regain d'intérêt ces dernières années. Une des raisons est l'inondation de cette zone par la création d'un réservoir lié au barrage de Ilısu et la destruction de monuments anciens qui en a résulté. La menace pesant sur la citadelle et le pont de Hasankeyf a fait la une des journaux. Ces destructions sont le leitmotiv de cette étude, dans laquelle les AA. ont fait un catalogue (p. 59-133) de sites antiques menacés (700 av. J.-C. à 636 ap. J.-C.), situés sur le parcours du Tigre de Mossul au Lac Hazar. Cette monographie est également un appel à agir.

2 Mis à part cet aspect moderne, cette région a longtemps possédé une position stratégique, d'abord pour les rois assyriens puis pour les Achéménides (p. 6-12), les Parthes, les Sassanides et les Romains. C'est ainsi que les AA. dédient un chapitre au Tigre comme voie de commerce, et un autre aux nombreux reliefs rupestres, pour la plupart difficilement accessibles. 


\section{AUTEURS}

\section{ASTRID NUNN}

Université de Munich 